\title{
AZ ONLINE TÉR HATÁSA AZ EMBERI VISELKEDÉSRE: CYBERCSAPDA
}

Nagy sikerü, komoly kritikai visszhangot kiváltó szakkönyv Mary Aiken The Cyber Effect (magyarul Cybercsapda) címen megjelent kötete, melynek üzenetére így reflektált a The Times recenzense: „Ha vannak gyerekei, tegyen félre mindent, és olvassa el ezt a könyvet.” A könyv pozitív fogadtatását jelzi, hogy 2016-ban a The Times az év könyvei, a Nature pedig a húsz legjobb tudományos olvasmány közé sorolta, és Aiken professzort beválasztották az Információbiztonsági Dicsőség Csarnokába.

A szerző azért döntött az olvasmányos stílus mellett, mert elsősorban nem a szakemberek, hanem a gyermekeket nevelők számára írta kiugróan fontos témájú könyvét. A hivatkozott kutatások, elemzések adataiból összeállított, közel 350 tételes, tudományos igényü bibliográfia, a terjedelmes fogalommagyarázat és a részletes tárgymutató a kötet végén kapott helyet. A fordító, Török Csaba kitünően oldotta meg a magyar nyelvre való átültetést és az új szakkifejezések magyarítását.

Mary Aikent a törvényszéki cyberpszichológia első számú szakértőjeként tartják számon a világban. Mint írja, munkájánál fogva naponta szembesül azzal, milyen hatást gyakorol az online tér a gyerekekre és a tinédzserekre: „ha gyerekekről van szó, az internet a dugába dől”. Milyen okokra vezethető ez vissza? Elsősorban arra, hogy annak idején az internet tervezői a felnőtt felhasználókat tartották szem elött, és egyáltalán nem voltak tekintettel a gyerekekre. A hőskorban a világhálót a tudományos információ és a digitalizált kulturális örökség közzétételére szánták, de néhány évtized alatt hatalmas erejü, felfoghatatlan profitot termelö, globális iparággá vált. A digitális technológiáról szóló nyilvános diskurzus nyomasztóan megosztó: a rajongók magasztalják az online elérhető termékeket, a kritikusok viszont csak a nyilvánvaló hátrányokra koncentrálnak.

Való igaz: az internettechnológia jó is, rossz is - erre az ellentmondásra pedig az a helyes válasz, ha kitaláljuk, hogyan lehet a jelenséggel intelligensen együtt élni. Ehhez azonban meg kell értenünk, mi, hogyan és miért úgy müködik. Mary Aiken pszichológusként ehhez a megértéshez kíván hozzájárulni. Úgy tűnhet, inkább a technológia negatív aspektusaira összpontosít, ezzel azonban az a célja, hogy a vitát visszavezesse a kiegyensúlyozott középpontba azáltal, hogy a laikusoknak is megmagyarázza, milyen pszichológiai folyamatok állnak az cybertérben kialakuló viselkedésminták mögött.

A kötet három központi fejezete a digitális technológia gyermekekre és fiatalokra gyakorolt hatását mutatja be. A szerző nem rejti véka alá a véleményét: 
a felnőtt társadalom bünös gondatlanságot tanúsít, amiért türi, hogy a digitális technológia kárt okozzon a gyermekeknek, kitéve őket a pornográfia, a pedofília, az internetes zaklatás veszélyeinek. Ez részben a szülők - többnyire hozzá nem értésből fakadó - elnéző magatartásának köszönhető, de az igazi felelősök a technológiai ipar irányítói, akik nem vállalják a felelősséget az általuk előidézett veszélyekért és az okozott károkért.

A Facebook például láthatóan vonakodik saját szabályának érvényesítésétől, amellyel megakadályozhatná, hogy a tizenhárom évesnél fiatalabb gyermekek hamis adatokkal nyithassanak egyéni fiókot. A cég állítólag nem rendelkezik a kérdés megoldására szolgáló megoldással - ennek következtében viszont sok millió (!) tizenhárom év alatti gyermek férhet hozzá a közösségi oldalak akár „18+-os” tartalmaihoz, és teszi ki magát a cybertér veszélyeinek. Jól ismert tény, hogy a közösségi oldalakon dívó cyberbullying célkeresztjébe kiváltképp a kiskamaszok kerülnek. Miért nem tesznek semmit a szolgáltatások üzemeltetői a gyerekek elleni súlyos támadások elkerülése érdekében?

Az internetes zaklatás következményeivel hivatásszerüen foglalkozó szerző teljes joggal teszi föl a kérdést: ha a Big Data-állományok elemzésére szakosodott „közösségi analitikák” arra ki tudtak fejleszteni algoritmusokat, hogy meghatározzák (például a Twitter) felhasználóik nemét, életkorát, iskolázottságát, politikai és egyéb preferenciáit, akkor miért nem képesek kidolgozni az online zaklatást felderítő algoritmust? A kérdés nem költői: a szerző felállított egy egyenletet, melynek alkalmazhatóságát egy Palo Alto-i techcéggel együttmüködve vizsgálja.

Az ,Aiken-algoritmus”: $d x c(i \times f)=$ cyberbullying, ahol a $d$ (direction) jelzi, kire irányulnak a $c$ (content) gyülölködő kifejezések.

Az $i$ (intervallum) és az $f$ (frekvencia), vagyis az időtartam és a gyakoriság szorzata jelzi az online zaklatást.

A másik óriási probléma az egyre több embert a hatalmába kerítő, napjainkra elképesztő mértékủvé vált internetfüggöség. A közösségi média, az e-mailek, az online vásárlásra buzdító reklámok, a számítógépes játékok mind-mind arra késztetnek sok milliárd embert, hogy szinte percenként ellenőrizze okostelefonját, ne legyen képes kiszállni a kényszeres vásárlásból, a videójátékokból.

Aiken különösen a játékipar képviselöit ostorozza amiatt, hogy termékeiket tudatosan függőségre tervezik. A játékdizájnerek törekvése a minél addiktívabb, a játékosokat szabályosan beszippantó programok kifejlesztése. Hogyan alakul ki kényszeres internetfüggőség? „A viselkedés-lélektan tényként fogadja el, hogy az időszakos megerősítés sokkal hatékonyabb motiváló erő, mint a folyamatos jutalmazás" - írja Aiken. Sokkal valószínúbb az ismétlődés, ha a viselkedés jutalma az élvezet. A játéktervezés pszichológiája azon alapul, hogy a játékos belekerül a „fun failure” - vagyis a „szórakoztató kudarc” - örvényébe, mert a végén hiába veszít, a győzelem előérzete elég ahhoz, hogy elindítsa a biokémiai élvezethullámot. 
Az online világ lényegében a Maslow-féle „szükségletpiramis” összes elemét: „a fiziológiai szükségletektől kezdve a biztonság, a szeretet, az összetartozás, a megbecsülés, az önismeret és az önmegvalósítás szükségletét" kielégíti. A biztonságot a névtelenségbe rejtőzés szolgálja, az online szörfölés a felfedezés örömét nyújtja, egy idő után pedig a végtelen cybertérben kalandozás addikcióvá válhat, akárcsak a drog és az alkohol. A függő embert a dopamin tartja a szünet nélküli éber várakozás állapotában.

A káros jelenségek közül Aiken talán a legriasztóbbnak azt tartja, hogy egyre több csecsemő fér hozzá a technológiához. A szülők bedőlnek a reklámoknak, amelyek a pár hónapos babák agyát „stimuláló, fejlesztő” termékek vásárlására ösztönzik őket. Az USA-ban a 2000-es években pert indítottak a csecsemőknek készülő piacvezető termékek elóállítói ellen; a perek kapcsán számos tudományos kutatás igazolta, milyen károkat okoz, ha a kisbabák életük első két évében képernyőt néznek. A kisgyermekeket a beszéd és más kognitív készségek fejlesztésében a környezetükkel folytatott valóságos interakciók segítik; ezen a téren kétéves kor alatt a televízió és az online müsorok nemhogy nem használnak, inkább kárt okoznak az érzelmi és értelmi fejlődésben.

Az Aiken által tárgyalt további témák: a sok visszaélésre lehetőséget adó online párkeresés, a tüneteiket felnagyító képzelt betegek, illetve a sötét bünök melegágya, a rejtőző Deep Web. Az internetet jól ismerőknek meg kell küzdeniük a kognitív disszonancia problémájával - azzal, hogy a világháló egyrészt javítja életminőségüket, növeli tudásukat és képességeiket, másrészt viszont az adathalászok, a hackerek, a zaklatók miatt állandó fenyegetettségben élnek -, és ez az ellentmondás folyamatos belső feszültséget kelt.

A digitális technológia életünk minden aspektusába behatolt, megváltoztatja viselkedésünket, szokásainkat, túlzottan nagy hatást gyakorol gyermekeinkre, és - nem mellesleg - lehetővé teszi a politikai befolyásolást, fölerősíti a visszataszító, antiszociális megnyilvánulásokat, tág terepet nyújt a bünözők számára. A digitális technológia következményeit látva egyre többen vallják, hogy föl kell lépni a káros hatások ellen - különösen a gyerekek védelme terén.

A mélyen elgondolkodtató könyv egyúttal intő kiáltvány a felnőttek számára. Ahogy a szerző fogalmaz: „Itt az ideje, hogy olyan digitális környezetet követeljünk, amely tiszteletben tartja a gyermekkort.”

(Mary Aiken: Cybercsapda. Hogyan változtatja meg az online tér az emberi viselkedést? Budapest, Harmat Kiadó-Magyar Kurir, 2020, 412 o.)

Tószegi Zsuzsanna

PhD, címzetes egyetemi docens Eötvös Loránd Tudományegyetem Bölcsészettudományi Kar Könyvtár- és Információtudományi Intézet 